\title{
PERAN MANUSIA SEBAGAI KHALIFAH ALLAH DI MUKA BUMI PERSPEKTIF EKOLOGIS DALAM AJARAN ISLAM
}

\author{
Watsiqotul, Sunardi, Leo Agung \\ Program Magister Pendidikan Sejarah \\ Fakultas Keguruan dan Ilmu Pendidikan,Universitas Sebelas Maret, \\ Surakarta \\ Viey.elwatsiq@gmail.com
}

\begin{abstract}
Kerusakan alam dan lingkungan hidup yang lebih dabsyat bukanlah disebabkan oleh proses alam yang semakin tua, akan tetapi justru akibat dari ulah tangan-tangan manusia yang selalu berdalih memanfaatkannya. Dalam ajaran islam banyak hadis dan ayat akan kewajiban manusia untuk mengelola alam dan menjaga akan diminta pertanggungjawabannya, sehingga manusia tidak berhak berlaku sewenang-wenang dalam memimpin dan mengelola alam. Dalam penelitian ini akan lebih jauh dibahas bagaimana peran manusia sebagai khalifah di muka bumi dalam perspektif ekologis sesuai ajaran islam. Perumusan masalah dalam penelitian ini adalah; 1) bagaimana peran manusia sebagai khalifah dari perspektif ekologis dalam ajaran islam?; 2) bagaimana manusia sebagai klahifah dimuka bumi dalam menjaga dan memelibara alam? Tujuan dari penelitian ini adalab; 1) untuk. mengetahui peran manusia sebagai khalifah dari perspektif ekologis dalam ajaran islam; 2) manusia sebagai khalifah dimuka bumi dalam menjaga dan memelibara alam. Penelitian ini menggunakan pendekatan penelitian deskriptif kualitatif jenis dengan jenis penelitian studi
\end{abstract}


pustaka. Penelitian kepustakaan di lakukan melalui buku, majalah, jurnal, internet dan sebagainya. Selain itu dengan melakukan studi pengamatan dari penelitian-penelitian sebelumnya. Hasilyang ditemukan yaitu; 1) bahwa alam adalab segala sesuatu yang diciptakan Allah dengan segala isinya, dalam konteks ini, bahwa alam tidak, hanya benda angkasa atau bumi dan segala isinya, tetapi alam juga terdapat diantara keduanya, tugas dari seorang khalifah menjadikan perlindungan bagi umat dan menjaga kelestarian alam (ekosistem), sehingga khalifah dan umat harus bersatu dan saling mencintai guna menjalankan kehidupan sesuai dengan syariat islam dan keberlangsungan bidup. 2) manusia adalah khalifah di muka bumi, tugas khalifah dalam Al Qur'an biasa disebut imaratul ardh (memakmurkan bumi) dan ibadatullab (beribadah kepada Allah). Allah menciptakan manusia dari bumi ini dan menugaskan manusia untuk melakukan imarab dimuka bumi dengan mengelola dan memeliharanya.

Kata Kunci : Peran, Khalifah, Ekologis, Ajaran Islam, Al-Quran

\section{A. Pendahuluan}

Islam merupakan agama dominan kedua yang dianut oleh umat didunia, khususnya masyarakat Indonesia. Saat ini, Islam masih ada di peringkat kedua dengan jumlah pemeluk sebanyak 1,59 miliar jiwa atau sekitar $23 \%$ dari total populasi dunia, jumlah muslim diperkirakan akan naik hampir dua kali lipat, dengan perkiraan mencapai 2,7 miliar muslim pada 2050, ini akan menjadikan $29 \%$ penduduk dunia nantinya adalah orang Islam (Tirto.id, 2017) ${ }^{1}$.

Dalam ajaran islam sangat menganjurkan dan peduli akan alam, bahkan sangat banyak ayat-ayat Al-Quran yang memerintahkan manusia untuk memelihara dan mengelola alam guna keberlangsungan hidup manusia, sehingga manusia mesti peka terhadap isu-isu lingkungan hidup. Hubungan agama islam dan konsep ekologis islam menurut Nasr bahwa krisis yang dialami manusia, salah satunya yaitu krisis lingkungan yang terjadi akibat dari ulah manusia

1 Khadafi, Ahmad. 2017. Saat Islam Menjadi Agama Mayoritas di Dunia. bttp:/ / khalifah/Saat-Islam-Menjadi-Agama-Mayoritas-di-Dunia, Tirto.ID.htm, diupload tgl- 6 April 2017 
modern yang cenderung meninggalkan dimensi spiritualitasnya ${ }^{2}$. Dengan semakin canggihnya teknologi menjadikan manusia modern mudah megeksploitasi alam tanpa menggunakan unsur spiritualnya. Pandangan spiritualitas menurut Nasr merupakan hal yang sangat penting dalam kehidupan manusia demi keberlangsungan bumi dan isinya. Kerusakan alam dan lingkungan hidup yang lebih dahsyat bukanlah disebabkan oleh proses alam yang semakin tua, akan tetapi justru akibat dari ulah tangan-tangan manusia yang selalu berdalih memanfaatkannya, yang sesungguhnya sering kali mengeksploitasi tanpa mempedulikan kerusakan-kerusakan lingkungan yang ditimbulkannya (Fadjar, 2005)3.

Hasil riset pada masyarakat kontemporer yang antara lain dilakukan oleh Intergovernmental Panel On Climate Change (IPCC) serta puluhan badan riset dalam kelompok G-8 (Negaranegara maju) dan G-20 (Negara ekonomi besar berjumlah 20) menyimpulkan bahwa peningkatan suhu permukaan bumi, kerusakan lingkungan hidup serta terkurasnya sumber daya alam disebabkan oleh aktivitas manusia sepanjang sejarah, sehingga dalam skala global, eksplotasi sumber daya alam yang semakin intensif di berbagai kawasan dunia dilakukan oleh masyarakat industri yang nampaknya tidak memiliki kompetensi dan kecerdasan ekologis (Supriatna, 2016) ${ }^{4}$.

Kerusakan sumber daya alam (tanah, air dan udara), terjadinya deforestasi dan degradasi hutan bahkan kebakan hutan yang sering terjadi yang mengakibatkan menipisnya dan musnahnya hayati, hingga terjadinya permukaan air laut naik dan tenggelamnya beberapa pula, serta merebaknya berbagai jenis penyakit merupakan berbagai bentuk masalah akibat terjadinya krisis lingkungan, sehingga menuntut adanya solusi segera dalam

${ }^{2}$ Masrokhin.Konsep Ekologi Islam Seyyed Hossein Nasr (Studi Kitab Al-Taharah dalam Kajian Fiqih),Konsep Ekologi Islam, Jurnal Irtifaq, Vol. 1, No 1, 2014.

4 Supriatna, Nana. 2016.Ecopedagogy. Bandung: Remaja Roesdakarya,
2016. 
menanggulangi hal tersebut, hal-hal demikian terjadi akibat perilaku eksploitasi dan konsumtif manusia yang berlebihan (serakah) dengan menganggungkan paradigma antroposentrisme. Pandangan antroposentrisme yaitu anggapan bahwa manusia bukan merupakan dari alam, melainkan manusia adalah hasil cipta Tuhan, yang diciptakan untuk mengatur dan menaklukkan alam. Dengan pandangan tersebut menimbulkan dualisme antara manusia berada di satu pihak dan alam berada dipihak lain, oleh sebab itu, terjadinya eksploitasi manusia terhadap alam dalam pandangan antroposentrisme merupakan perwujudan kehendak Tuhan, karena manusia diciptakan untuk menguasai dan menaklukkan alam.

Manusia merupakan makhluk ciptaan Allah yang terbesar dan teristimewa di antara makhluk lainnya, sehingga manusia mampu mewujudkan perbuatan yang paling tinggi pula. Mufid $(2010)^{5}$ manusia sebagai makhluk kosmis (microcosmos, istilah dari Ibnu Maskawih) yang dibekali dengan perangkat lengkap dengan semua persyaratan, syarat yang menyatakan bahwa manusia sebagai suatu kesatuan jiwa raga dalam hubungan timbal balik dengan dunia dan sesamanya.

Di era modern ini peniadaan hal-hal yang bersifat sakral (tardisi) menjadikan penyebab terjadinya krisis ekologi, hal ini sejalan dengan pendapat Nasr (dalam Syakur, 2008) ${ }^{6}$ bahwa peniadaan hal-hal yang bersifat sakral dalam era modern ini merupakan salah satu faktor penyebab terjadinya krisis ekologi dan proses dehumanisasi yang menyertainya seperti yang diderita saat ini. Bahkan akar-akar budaya modernitas yang dianggap sebagai penyebab terserabutnya pandangan tradisional religius terhadap alam semesta, yakni alam sebagai tanda-tanda kebesaran sang pencipta. Krisis ekologi yang terjadi di muka bumi menjadikan diskusi-diskusi dalam bidang sains dan agama terasa mendesak, jika setiap manusia dari berbagai perspektif yang berbeda tidak Roesdakarya.

5 Mufid, Sofyan Anwar. 2010.Ekologi Manusia. Bandung: Remaja

${ }^{6}$ Syakur, M. Perspektif Pelestarian Lingkungan Hidup dalam Islam, Jurnal Ilmu-Imu Pertanian, Vol. 4. No. 1, hlm 44-56, 2008 
dapat menyepakati keprihatinan bersama akan dunia, maka sistem kehidupan di muka bumi terancam bahaya kehancuran akibat ulah daripada manusia.

Hasil dari penelitian Syakur ${ }^{7}$ dengan judul Perspektif Pelestarian Lingkungan Hidup dalam Islam, menyatakan bahwa di lingkungan umat islam pemahaman Al-Quran yang bersifat tematik dan yang bersifat komprehensif-utuh belum banyak dilakukan oleh pemikir muslim, sehingga pemikiran islam mengenai ekologi belum sepenuhnya terkaji. Terumat Islam dengan tradisi keberagamaannya seharusnya sadar akan adanya makna lebih mendalam dibalik ibadah formal yang mereka lakukan, sehingga tindakan mereka tidak hanya bersifat teosentrik, tetapi juga berdimensi ekososial sentris. Dengan pemahaman terhadap alam lingkungan dan kehidupan manusia diharapkan dapat memberikan sumbangan yang berbobot oleh cendekiawan agama untuk mengatasi krisis ekologi dan krisis global. Kemudian hasil penelitian kedua oleh Quddus ${ }^{8}$ dengan judul Ecotheology Islam: Teologi Konstruktif Atasi Krisis Lingkungan, menyatakan bahwa ecoteology islam bersumber dari ecotheology dan kosmologi sakral dapat berkontribusi positif sebagai guiding principles pengelolaan alam. Kontribusi tersebut nampak jelas pada beberapa prinsip ecotheologi islam yaitu: prinsip tawbid (unity of all creation), prinsip amanah-khalifah (trustworthinessmoral leadership), dan akhirah (responsibility).

Dengan ketiga prinsip tersebut yang membekali manusia dalam mengelola alam dan lingkungannya yaitu tawbid yaitu manusia menyadari bahwa manusia dan alam merupakan satu-kesatuan dan alam bukan milik manusia melainkan Allah, sehingga manusia hanyalah bersifat amanah, manusia hanya menjadi pemegang amanah atau titipan Allah berupa menjaga dan memelihara alam, bukan merusak dan eksploitatif alam. Dengan begitu manusia harus mempertanggung jawabkan setiap perbuatannya di akhirat

7 Ibid.

${ }^{8}$ Quddus, Abdul. Ecotheology Islam: Teologi Konstruktif Atasi Krisis Lingkungan, Ulumuba (Jurnal Studi Keislaman), Vol 16, No 2,2012. 
yaitu konsep akhirah yang menjadi bingkai atau rambu-rambu peringatan dalam pemanfaatan dan pengelolaan alam.

Berdasarkan pemaparan tentang masalah-masalah ekologi dan lingkungan hidup, dapat dikaji menjadi; 1) bagaimana peran manusia sebagai khalifah dari perspektif ekologis dalam ajaran islam?; 2) bagaimana manusia sebagai khalifah dimuka bumi dalam menjaga dan memelihara alam? Untuk menjawab permasalahan tersebut akan diuraikan dalam penulisan ini dengan merujuk pada berbagai literatur agama islam dan otoritatif dibidangnya.

\section{Kajian Pustaka}

\section{Definisi/Pengertian Khalifah}

Manusia bertanggung jawab terhadap keberlanjutan ekosistem karena manusia diciptakan sebagai khalifah (Nahdi, 2008) ${ }^{9}$. Dalam konteks Al-Quran memandang manusia sebagai "wakil" atau "khalifah" Allah di bumi, untuk memfungsikan kekhalifahannya Tuhan telah melengkapi manusia potensi intelektual dan spiritual sekaligus (Hafsin, 2007) ${ }^{10}$. Sesuai dengan UU RI Nomor 23 Tahun 1997 yang menyatakan pengertian lingkungan hidup itu sendiri yang didalamnya telah melibatkan peranan manusia dan perilakunya dalam menyejahterakan makhluk hidup dan dirinya. Karena secara etika manusia berkewajiban dan bertanggung jawab terbesar terhadap lingkungan dibandingkan dengan makhluk lainnya.

Allah menganugrahi akal kepada manusia, dan dengan akal itulah Allah menurunkan agama. agama sebagai petunjuk dan pedoman dalam kehidupan, merupakan dasar untuk mengatur bagaimana berhubungan dengan sang pencipta dan hubungan dengan alam semesta. Manusia dalam agama merupakan bagian

${ }^{9}$ Nahdi, Maize Said. Konservasi Ekosistem dan Keanekaragaman Hayati Hutan Tropis Berbasis Masyarakat. Jurnal Kaunia, Vol.4, No.2; hlm 159-172, 2008.

${ }^{10}$ Hafsin, Abu. 2007.Islam dan Humanisme: Akulturasi Humanisme Islam di Tengah Krisis Humanisme Universal. Yogyakarta : IAIN Walisongo dengan Pustaka Pelajar. 
dari lingkungan hidupnya, sehingga manusia ditunjuk sebagai khalifah di muka bumi ini. Seperti dalam firman Allah, yaitu:

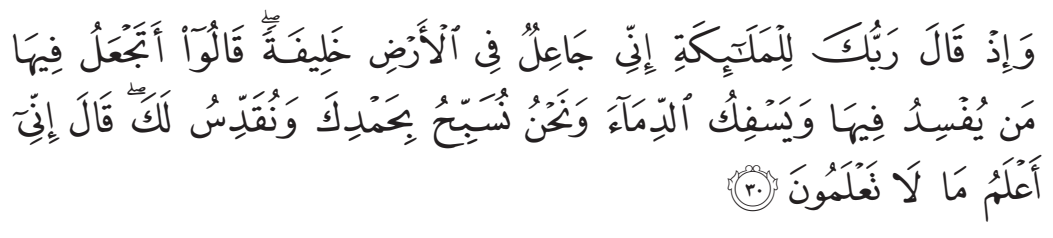

Yang artinya : "Ingatlah ketika Tubanmu berfirman kepada para Malaikat: "Sesunggubnya Aku hendak menjadikan seorang khalifah di muka bumi". Mereka berkata: "Mengapa Engkau hendak menjadikan (khalifah) di bumi itu orang yang akan membuat kerusakan padanya dan menumpabkan darah, padahal kami senantiasa bertasbih dengan memuji Engkau dan mensucikan Engkau?" Tuhan berfirman: "Sesunggubnya Aku mengetahui apa yang tidak kamu ketahui" (QS. Al- Baqarah [2] : 30).

Khalifah adalah orang yang mewakili umat dalam menjalankan pemerintahan, kekuasaan dan penerapan hukumhukum syariah (HTI, 2008) ${ }^{11}$. Khalifah adalah wakil umat dalam kehidupan di muka bumi. Seperti dalam firman Allah SWT:

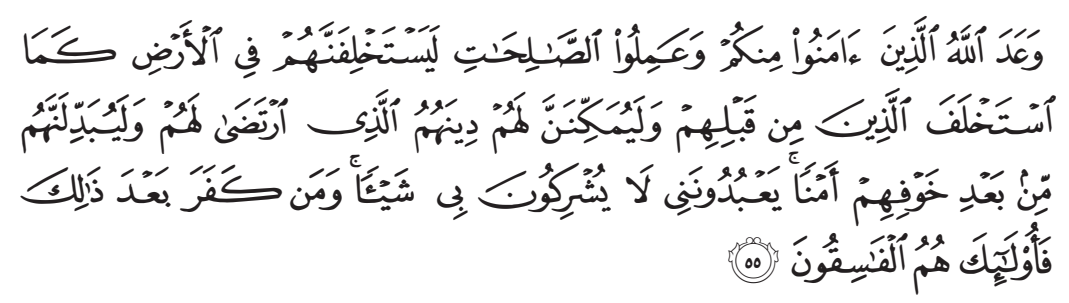

Yang artinya: "Allah telah berjanjian kepada orang-orang yang beriman dan mengerjakan amal-amal yang salih di antara kalian, bahwa Dia sungguh-sungguh akan menjadikan mereka berkuasa di bumi sebagaimana Dia telah menjadikan orangorang sebelum mereka berkuasa, akan menegubkan bagi mereka agama yang telah diridhai-Nya untuk mereka, dan akan menukar (keadaan) mereka setelah mereka berada dalam ketakutan menjadikan aman sentosa, mereka tetap menyebah-Ku tanpa mempersekutukan apapun dengan Aku. Siapapun yang sudah kafir sesudah janji itu maka mereka itulah orang-orang yang fasik” (Q.S. An-Nur [24]: 55).

Khalifah adalah sebutan yang diberikan kepada pemagang kekuasaan tertinggi dalam suatu pemerintahan islam, muncul Al-Ummah.

${ }^{11}$ Hizbut Tahrir Indonesia. 2008. Struktur Negara Khilafah. Jakarta : Dar 
pertama kali di Tsaqifah (Rumah) Bani Sa'idah yang merupakan suku di Madinah, berdasarkan prinsip pemilihan khalifah dari suku Quraisy (Usmani, 2016) ${ }^{12}$. Makna khalifah dalam islam sebagai satu-satunya pemimpin di seluruh penjuru dunia, sehingga khalifah menjadi pemimpin seluruh umat islam dari segala penjuru dunia.

Interaksi antara manusia dengan sumber-sumber alam harus berlangsung berdasarkan kaidah-kaidah yang diatur oleh Allah SWT dan sunnah Rasulullah SAW. Bahkan Allah mengamanahkan bumi kepada manusia untuk menyikapi ketentuan dan hukum- hukumnya.

\section{Ekologis dalam ajaran Islam}

Ekologis adalah ilmu tentang hubungan timbang balik antara makhluk hidup dengan lingkungan hidupnya. Lingkungan hidup menurut Soemarwoto (1987) ${ }^{13}$ adalah hubungan makhluk hidup, khususnya manusia, dengan lingkungan hidupnya, dalam pandangannya menyebutkan hubungan timbal balik tersebut adalah ekologi. Lebih lanjut lagi bahwa konsep sentral dalam ekologi merupakan ekosistem yang dimana suatu sistem ekologi yang terbentuk oleh hubungan timbal balik antara mankhluk hidup dengan lingkungannya.

Mufid (2010) ${ }^{14}$ ekologi merupakan ilmu dasar memahami dan meyelidiki alam bekerja, eksistensi kehidupan makhluk hidup dalam sistem kehidupannya, tentang kelangsungan hidup dalam habitatnya, cara mencukupi kebutuhannya, bentuk-bentuk interaksi dengan komponen dan spesies lain, tentang adaptasi dan toleransi terhadap perubahan yang terjadi, tentang pertumbuhan dan perkembangan yang berlangsung secara alami dalam sebuah ekosistem. Lingkungan hidup adalah ruang yang ditempati oleh

${ }^{12}$ Usmani, Ahmad Rofi'. 2016. Jejak-jejak Islam. Yogyakarta : Bunyan.

13 Soemarwoto, Otto. 1987. Ekologi, Lingkungan Hidup Dan Pembangunan. Jakarta: Djambatan.

${ }_{14}$ Mufid, Op.Cit. 
makhluk hidup bersama dengan benda-benda hidup dan tidak hidup didalamnya (Soemarwoto, 1987) ${ }^{15}$.

Haeckel adalah seorang ahli ilmu Yunani yang pertama kali mengenalkan atau menggunakan Istilah ekologi, yang beasal dari dua kata oikos yang berarti "rumah" dan logos yang berarti "ilmu". Soemarwoto (1987) ${ }^{16}$ Mengemukakan bahwa ekologis merupakan sebuah ilmu tentang makhluk hidup dalam rumahnya, yang dapat diartikan juga sebagai ilmu tentang rumah tangga makhluk hidup. Pada dasarnya semua agama mengatur segala kehidupan manusia, termasuk interaksi antara manusia dan alam. Hubungan antara manusia dan alam bersifat komprehensif, dari bagaimana manusia berperilaku terhadap alam ataupun lingkungannya. Bahkan secara tegas hubungan manusia dan alam harus terjalin secara harmonis demi terjalinnya kehidupan berkesinambungan, dalam semua ajaran agama, khususnya islam sangat banyak ayat dan hadits nabi untuk menjaga dan melestarikan lingkungan hidup secara keseluruhan.

Dalam perspektif Islam, alam adalah segala sesuatu selain Allah SWT, alam adalah segala sesuatu yang diciptakan Allah dengan segala isinya, dalam konteks ini, bahwa alam tidak hanya benda angkasa atau bumi dan segala isinya, tetapi alam juga terdapat diantara keduanya. Sehingga Allah menciptakan alam dengan sangat kompleks dan luas cakupannya (Muhaimin, 2015) ${ }^{17}$. Allah mempersilahkan kepada umat manusia untuk mengambil manfaat dan memberdayakan hasil alam dengan sebaik-baiknya demi kemakmuran dan kemasalahatan artinya manusia diberi kebebasan baik mengelola alam atau hanya sebatas mengambil manfaat dari alam, selagi manusia tidak mengakibatkan kerusakan pada alam.

Sehubungan dengan krisis lingkungan banyak ayat Allah yang memberikan peringatan kepada manusia tentang kerusakan

\footnotetext{
${ }^{15}$ Soemarwoto, Op.Cit

${ }^{16}$ Soemarwoto, Op.Cit

${ }^{17}$ Muhaimin. 2015. Membangun Kecerdasan Ekologis (Model Pendidikan untuk Meningkatkan Kompetensi Ekologis). Bandung: Alfabeta.
} 
lingkungan dan bahayanya bagi manusia. Seperti yang terkandung dalam surat Al-Baqarah [2] ayat 22, yaitu:

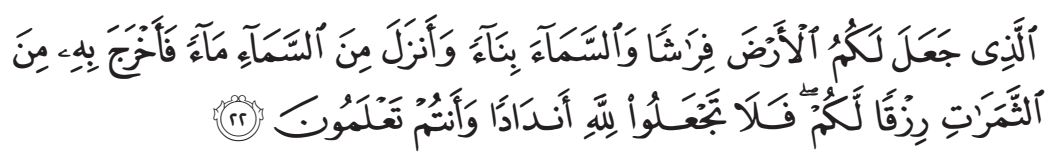

Yang artinya "dialah yang menjadikan bumi sebagai hamparan bagimu dan langit sebagai atap dan dia menurunkan air (bujan) dari langit, lalu dia menghasilkan dengan bujan itu segala buah-buahan sebagai reqki untukmu, karena itu janganlah kamu mengadakan sekutu-sekutu bagi Allah, padalah kamu mengetabui" (QS. Al- Baqarah [2]: 22).

Dalam agama Islam terdapat tingkatan pendidikan yang mempunyai peran penting dan strategis dalam mensosialisasikan dan mentransformasikan konsep, teori ilmu pengetahuan dan teknologi, yang diinternalisasikan dari nilai-nilai ajaran islam, bahkan termasuk konsep tentang ekologi dan lingkungan hidup kepada masyarakat dan peserta didik.

\section{Metode Penelitian}

Metode yang digunakan dalam penelitian ini adalah metode penelitian kualitatif, dengan jenis penelitian kepustakaan atau studi literatur. Penelitian kualitatif adalah suatu bentuk penelitian yang menghasilkan karya ilmiah yang menggunakan data deskriptif yang berupa kata tertulis atau lisan dari orang atau perilaku yang dapat diamati terhadap status sekelompok orang atau manusia, suatu objek dan suatu kelompok atau kebudayaan (Moleong, 2004) ${ }^{18}$. Penelitian yang dilakukan menggunakan pendekatan deskriptif kualitatif yaitu penelitian yang berusaha memberikan penjelasan yang cermat tentang situasi-situasi sosial yang berupa uraian kelimat dan datanya tidak berhubungan dengan angkaangka (Arikunto, 2012) ${ }^{19}$. Sedangkan pengertian jenis metode Rosdakarya.

${ }^{18}$ Moleong, L.J. 2004. Metodologi Penelitian Kualitatif. Bandung: Remaja

${ }_{19}$ Arikunto, S. et.al. 2012. Penelitian Tindakan Kela: Pendekatan Kuantitatif, Kualitatif, Dan R\&D. Bandung: Alfabeta. 
kualitatif studi literatur atau penelitian kepustakaan (library research) adalah serangkaian kegiatan yang berkenaan dengan metode pengumpulan data pustaka-pustaka, membaca sumbersumber pustaka dan mencatat hasilnya, kemudian mengelola bahan penelitian (Zed, 2008) ${ }^{20}$.

Dengan pengertian lain studi pustaka yaitu peneliti mempelajari dan mengumpulkan data melalui literatur dan sumber bacaan yang relevan dan mendukung penelitian. Dalam hal ini penelitian kepustakaan di lakukan melalui buku, majalah, internet dan sebagainya. Selain itu dengan melakukan studi pengamatan dari penelitian-penelitian sebelumnya. Data-data yeng dikumpulkan berasal dari textbook, jurnal, artikel ilmiah, literature review yang berisikan tentang konsep yang diteliti.

\section{B. Hasil dan Pembahasan}

\section{Peranan manusia sebagai khalifah (Khalifah Allah di Muka Bumi)}

Kekhalifahan manusia di satu pihak berperan sebagai subjek dan di sisi lain menjadi objek, sebagai subjek, manusia mempunyai tanggung jawab yang lebih kompleks dalam meningkatkan kualitas dirinya. Seperti dalam LKNU menyatakan bahwa Manusia berkualitas harus bercermin keimanannya, sehat jasmani dan rohani, berpendidikan, mengerjakan amal saleh, berbuat baik kepada orang lain, bertanggung jawab terhadap keluarganya, bertanggung jawab terhadap keluarganya, arif terhadap lingkungan hidupnya (Mufid, 2010) ${ }^{21}$.

Dalam konsep ekologi manusia, terdapat berbagai macam pandangan dalam memandang hubungan antara manusia dan alam. Islam mengakui keberadaan semua makhluk hidup di muka bumi sebagai kesatuan atas penciptaan dari sang khalik, sehingga jika terjadi kerusakan terhadap ciptaan Allah, hal ini merupakan Indonesia.

${ }^{20}$ Zed, Mestika. 2008.Metode Penelitian Kepustakaan . Jakarta : Yayasan Obor ${ }^{21}$ Mufid, Op.Cit. 
pengingkaran terhadap ciptaan Allah. bahkan lebih dalam lagi, islam memiliki prinsip-prinsip dasar dalam upaya melestarikan lingkungan hidup dan sumber daya alam.

Kewajiban manusia untuk mengelola alam dan menjaga akan diminta pertanggungjawabannya, sehingga manusia tidak berhak berlaku sewenang-wenang dalam memimpin dan mengelola alam. Mengenai kewajiban manusia sebagai khalifah atau penguasa (pemimpin) yang harus bertanggung jawab atas perbuatannya terdapat pada hadits nabi yaitu "masing-masing kamu adalab orang yang bertanggung jawab, maka akan diminta (kelak) pertanggungjawabannya, raja adalah orang yang bertanggung jawab atas rakyat yang dipimpinya, dan dia (penguasa) akan dimintai pertanggungjwabannya tentang mereka, seorang laki-laki kepala rumah tangga bertanggung jawab atas keluarganya dan akan dimintai pertanggungjawabannya tentang mereka, dan seora ng perempuan sebagai ibu rumah tangga harus bertanggung jawab atas suami dan anak-anaknya dan akan dimintai pertanggungjawabannya tentang mereka, pembantu bertanggung jawab atas harta majikannya, dan akan diminta pertanggungjawabannya tentang itu, ingatkah babwa masing-masing kamu adalah orang yang bertanggung jawab, dan setiap kamu akan dimintai pertanggungjawaban atas apa yang kamu lekolanya" (HR. Imam Bukhari dari Abdullah Ibnu Umar).

Islam sebagai agama dalam kehidupan sejatinya memiliki visi dan misi rahmah li al-Alamin (kebaikan bagi semesta alam), dengan mewujudkan visi dan misi tersebutlah Allah menugaskan kepada manusia sebagai khalifah di Bumi. Seperti yang dijalaskan dalam surat Al-Ahzab [33] ayat 72, yaitu:

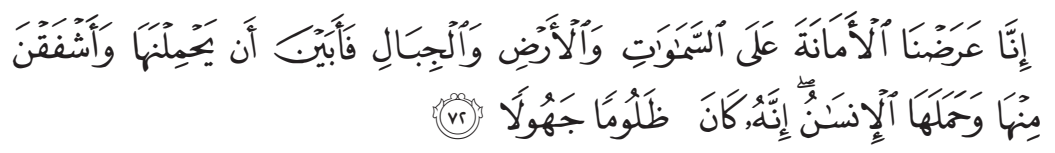

Yang artinya: "Sesungguhnya kami telah mengemukakan amanah kepada langit, bumi dan gunung-gunung, maka semuanya enggan untuk memikul amanah itu dan mereka khawatir akan menghianatinya, dan dipikullah amanah itu oleh manusia, sesunggubnya manusia itu amat zalim dan amat bodob" (QS.Al-Ahzab [33 ]: 72). 
Tugas manusia sebagai khalifah adalah untuk menjaga dan bertanggungjawab atas dirinya, sesama manusia dan alam yang menjadi sumber penghidupan. Karena sudah menjadi kewajiban bagi manusia yang merupakan khalifah di bumi memiliki dua bentuk sunatullah yang harus dilakukan, yaitu baik kewajibannya antara manusia dengan tuhannya, antara sesama manusia sendiri, dan antara manusia dengan ekosistemnya. Kewajiban tersebut haru dilaksanakan karena merupakan amanah dari Allah sang pencipta. Tanggung jawab manusia terhadap moral agama sebagai khalifah di bumi yaitu mengelola sebaik-baiknya alam semesta dan kehidupan sosial didalamnya. Kehidupan manusia sangat tergantung kepada komponen-komponen lain dalam ekosistem sehingga secara moral manusia terhadap alam dituntut untuk bertanggungjawa kepada kelangsungan, keseimbangan dan kelestarian alam yang menjadi sumber kehidupannya.

Menjaga keseimbangan dan kelestarian lingkungan hidup, baik alam ataupun lingkungan sosial merupakan tugas daripada khalifah dalam upacara memformasi bumi, Madjid menegaskan bahwa muara dari semua prinsip kekhalifahan manusia adalah reformasi bumi (Madjid, 2009)22. Permasalahan lingkungan alam semakin berkembang seiring berjalannya waktu dan saling terkait secara global. Bahkan masing-masing manusia dalam setiap negara berlomba-lomba merusak sumber daya alam dengan dilakukannya pembangunana yang dilakukan, khususnya yang paling banyak berada di negara berkembang.

Tugas dari seorang khalifah menjadikan perlindungan bagi umat dan menjaga kelestarian alam (ekosistem), sehingga khalifah dan umat harus bersatu dan saling mencintai guna menjalankan kehidupan sesuai dengan syariat islam dan keberlangsungan hidup.

Tugas khalifah dalam Al Qur'an biasa disebut imaratul ardh (memakmurkan bumi) dan ibadatullah (beribadah kepada

\footnotetext{
${ }^{22}$ Madjid, Nurcholish. 2009.Cita-Cita Politik Islam . Jakarta : Paramadina \& Dian Rakyat.
} 
Allah). Allah menciptakan manusia dari bumi ini dan menugaskan manusia untuk melakukan imarah dimuka bumi dengan mengelola dan memeliharanya. Tugas kekhalifahan terhadap alam (natur) meliputi ${ }^{23}$ :

a. Mengulturkan natur (membudayakan alam), yakni alam yang tersedia ini agar dibudayakan, sehingga menghasilkan karya- karya yang bermanfaat bagi kemaslahatan hidup manusia.

b. Mengulturkan kultur (mengalamkan budaya), yakni budaya atau hasi karya manusia harus disesuaikan dengan kondisi aam, jangan sampai merusak alam atau lingkungan hidup, agar tidakmenimbulkan malapetaka bagi manusia dan lingkungannya.

c. MengIslamkan kultur (mengIslamkan budaya), yakni dalam berbudaya harus tetap komitmen dengan nilainilai Islam yang rahmatan lil-'alamin, sehingga berbudaya berarti mengerahkan segala tenaga, cipta, rasa dan karsa, serta bakat manusia untuk mencari dan menemukan kebenaran ajaran Islam atau kebenaran ayat-ayat serta keagungan dan kebesaran Ilahi.

Konsep khalifah sebagai yang telah dikemukakan diatas menunjukkan bahwa dalam ajaran islam memiliki relevansi dan perhatian yang sangat besar terhadap konsep ekologis dan lingkungan hidup. Sehingga untuk itu, ajaran islam mengenai konsep ekologis dan lingkungan hidup perlu dikonstruksi sebagai sistem, keyakinan akan nilai-nilai dan cita-cita lingkungan hidup, yang dapat dipahami, ditransformasikan dan diinternalisasikan oleh seluruh umat untuk diperjuangan guna mewujudkan citacita tersebut. Sehingga peranan khalifah di muka bumi sangatlah penting dalam menjaga keseimbangan alam atau lingkungan hidup. Seperti yang dijlaskan dalam surat Al-An'am [6] ayat 165, yaitu:

23 Wahyu Supraptiningtyas.Tugas Manusia Sebagai Khalifah di Muka Bumi. bttp://blog.unnes.ac.id/malikhatundayyanah/2015/11/24/tugas.manusia-sebagaikhalifah-di-muka-bumi/diupload, pada Minggu, 21 Agustus 2011 21:34 WIB 


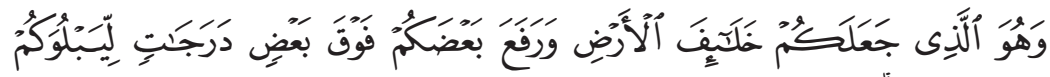

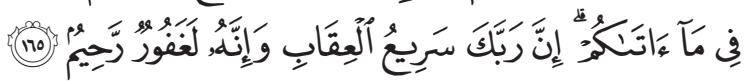

Yang artinya: "Dan dialah yang menjadikan kamu sebagai khalifahkhalifah di Bumi dan Dia mengangkat (derajat) sebagian kamu di atas yang lain, untuk mengujimu atas (karunia) yang diberikan-Nya kepadamu. Sesungguhnya Tubanmu sangat cepat memberi bukuman, dan sunggub Dia Maha Pengampun, Maba Penyayang" (QS.Al-An'am [6]: 165)”.

Kemudian dijelaskan pula pada Surat Al al-A'raf ayat 7 dan ayat 17 sebagai berikut:

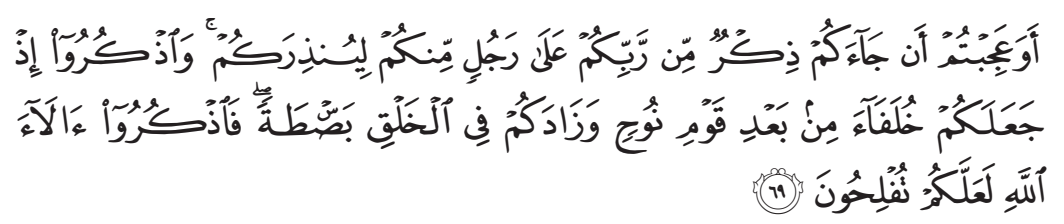

"Dan hendakah kamu bahwa ada peringatan yang datang dari Tuhanmu melalui seorang laki-laki dari kalanganmu, untuk memberi peringatan kepadamu? Ingatlah ketika Dia menjadikan kamu sebagai khalifah-khalifah setelab kamu Nuh, dan Dia lebihkan kamu dalam kekuatan tubuh dan perawakan, Maka, Ingatlah akan nikmat Allah agar kamu beruntung"(QS. Al-A'raf [7]: 69).

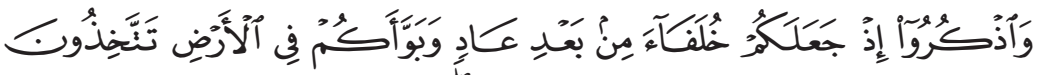

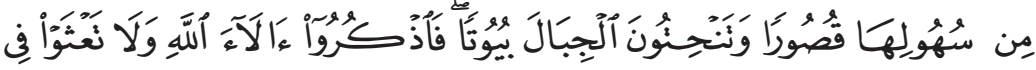

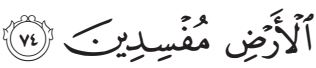

Yang artinya: "Dan ingatlah ketika Dia menjadikan kamu khalifah-khalifah setelah kaum 'Ad dan menempatkan kamu di bumi. Di tempat yang datar kamu dirikan istana-istana dan bukit-bukit kamu pahat menjadi rumah-rumah. Maka ingatlah nikmat-nikmat Allah dan janganlah kamu membuat kerusakan di Bumi" (QS. Al- A'raf [7]: 74).

Dan dalam suratAl-Isra [17]: 37, sebagai berikut:

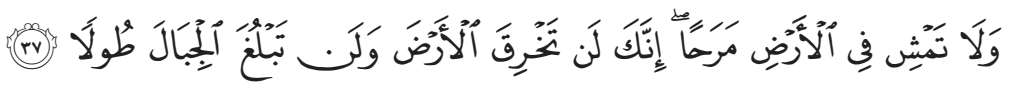

Yang artinya: "Dan janganlah engkau berjalan di Bumi ini dengan sombong, karena sesunggubnya engkau tidak akan dapat menembus bumi dan tidak akan mampu menjulang setinggi gunung (QS.Al-Isra '[17]: 37)”. 
Bahkan dalam selain dalam surat Al-Isra' dijelaskan pula dalam surat Al-Anbiya [21]: 31, sebagaimana dijelaskan akan penciptaan bumi dan isinya dan sebagaimana mereka berjalan sesuai perintah Allah, dalam firman Allah yaitu:

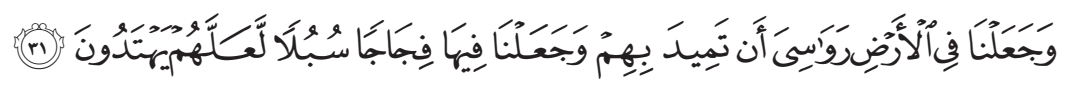

Yang artinya: "Dan Kami telah menjadikan di Bumi ini gunung-gunung yang kukuh agar (tidak) guncang bersamaan dan Kami jadikan (pula) di sana jalan-jalan yang luas, agar mereka mendapat petunjuk.” (QS.Al-Anbiya [21]: 31).»

Pengertian maksud daripada ayat diatas menjelaskan bahwa Allah telah menciptakan tempat yang baik bagi manusia sebagai tugas kekhalifahan dan memerintahkan kepada manusia untuk memakmurkannya. Sehingga manusia harus menjaga dan melestarikan bumi dan lingkungannya karena menjadi bagian dari tugas manusia sebagai khalifah. Seperti yang dijelaskan pada surat An-Naml [27]: 62, yaitu sebagai berikut:

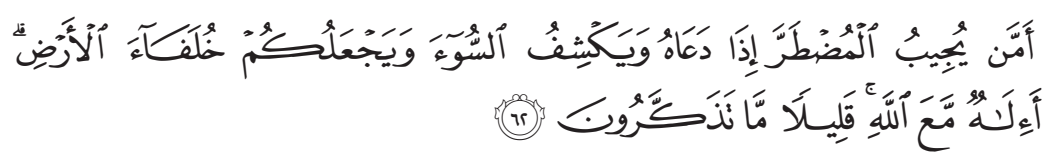

"Bukankah Dia (Allah) yang memperkenankan (doa) orang yang dalalm kesulitan apabila dia berdoa kepada-Nya dan menghilangkan kesusahan dan menjadikan kamu (manusia) sebagai khalifah (pemimpin) di Bumi? Apakah di samping Allah ada Tuban (yang lain)? Sedikit sekali (nikmat Allah) yang kamu ingat" (Qs. An- Naml [27]: 62).

\section{Peran Khalifah dan Pengetahuan Ekologis}

Hubungan manusia sebagaimana sebagai hamba Allah dan diutus menjadi Khalifah di muka bumi memiliki posisi saling terkait kuat, karena dalam tugas manusia sebagai khalifah memiliki wewenang mengelola dan mengatur bumi beserta isinya. Sedangkan tugas manusia sebagai hamba, manusia melakukan segala aktivitas sesuai dengan aturan Allah dan bertanggungjawab atas semua tindakannya. 
Pandangan Domanska (dalam Supriatna 2016) ${ }^{24}$ memandang hubungan manusia dengan lingkungan alam melalui peran negara maju dan negara berkembang dalam mengeksplotasi Sumber Daya Alam. Dengan menyimpulkan bahwa negara-negara maju lebih banyak menyumbang kerusakan lingkungan daripada negara tertinggal, karena eksplotasi terhadap alam dilakukan secara besarbesaran untuk mencapai kemajuan teknologi. Sedangkan dalam kawasan periphery, eksploitasi terhadap lingkungan disebabkan karena faktor kemiskinan dan rendahnya kebijakan politik dan ekonomi yang mendukung pelestarian alam.

Munculnya teori Darwin tentang survival of the fiftest telah menempatkan manusia sebagai makhluk yang lebih unggul dari makhluk lainnya, sehingga manusia berusaha menguasai alam dan mampu menklukan alam. Hal tersebutlah menyebabkan terjadinya kerusakan alam di berbagai belahan bumi. Dampak dari teori Darwin semakin menunjukkan bahwa manusia tidak lagi menjadi makhluk yang bergantung kepada alam, melainkan manusia menjadi faktor penentu atas keberlangsungan alam. Dampak negatif dari hal tersebut semakin menjadikan manusia mencapai level tinggi dalam pengelolaan alam, sehingga semakin mempercepat proses kerusakan alam karena terjadinya eksploitasi akan Sumber Daya Alam secara besar-besaran.

Selain itu krisis lingkungan yang terjadi disebabkan oleh berbagai faktor seperti pertumbuhan penduduk, industrialisasi, urbanisasi, pengeseran fungsi lahan, deforestasi, konflik antar etnik memperebutkan wilayah dan lain-lain (Supriatna, 2016) ${ }^{25}$. Islam telah melarang manusia untuk melakukan eksploitasi dan pengerusakan terhadap alam dan spesies tumbuhan serta hewan. Seperti halnya dalam surat Al-A'raf [7]: 31:

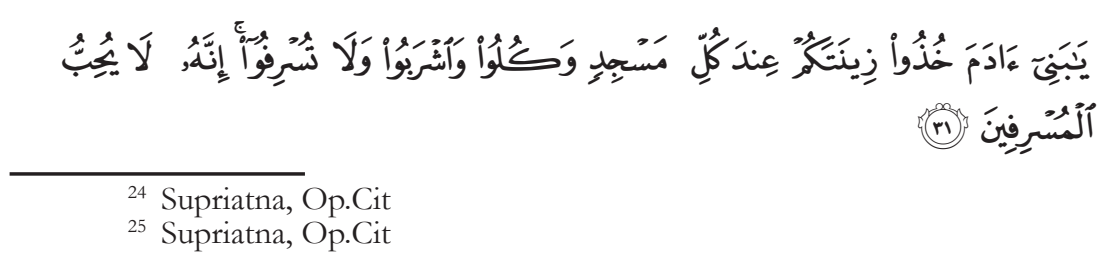


Yang artinya: "wahai anak cucu adam! Pakailah pakaianmu yang bagus pada setiao (memasuki) masjid, makan dan minumlah, tetapi jangan berlebihan. Sungguh Allah tidak menyukai orang yang berlebib-lebihan” (QS. Al-A'raf [7]: 31).

Makna dalam kandungan ayat tersebut menyatakan bahwa islam telah mengatur manusia dalam mengelola dan memanfaatkan alam dengan porsi dan batasan agar tidak merusak alam, tidak boros (mubazir), tidak serakah dan tidak menyia-nyiakannya yang tidak diperlukan.

Pemikiran Agama Islam dalam beberapa prinsip dasar yang terkait lingkungan dan menjadi basis elaborasi konsep ekologis dalam islam, sebagai berikut (Quddus, 2012) ${ }^{26}$ :

\section{a. Tawbid:unity of all creation}

Tawbid merupakan basis atau kerangka dasar bagi keseluruhan pandangan dan worldview-nya. Tawbid seperti khazanah yang dipadatkan, meskipun sederhana dalam permukaannya namun ketika diuraikan secara detail akan mencakup seluruh islam. Tawbid menjadi intisari dalam setiap agama yang dibawa oleh para nabi sebelum kedatangan Islam yang dibawa Nabi Muhammad. Hakikat Tawbid penyerahan diri secara utuh (bulat) kepada kehendak Allah, menyangkut ibadah dan mu'amalah, sehingga tawbid menjadi dasar seluruh konsep umat islam baik ekonomi, politikk, dan sosial-budaya. Cara padang tawbid melihat segalanya tentang alam bersumber dari Allah dan akan kembali kepada-Nya. Sehingga alam diciptakan dengan tujuan keberlangsungan hidup manusia dan wajib memelihara ciptaan Allah beserta segala isi didalamnya. Pandangan manusia sebagai khalifah tidaklah menjadikan manusia sebagai pemegang mutlak pada dirinya dan alam, karena segala sesuatu yang dimiliki manusia berasal dari Tuhan, dan tugas manusia hanyalah menjaga dan memelihara serta menggunakan sesuai kebutuhannya. Dalam konteks krisi lingkungan, tawbid menjadi nilai dasar manusia dalam memahami alam, alam yang dapat mengantarkan manusia untuk sampai pada realitas sejati.

\footnotetext{
${ }^{26}$ Quddus, Op.Cit
} 


\section{b. Amanah}

Manusia dan alam semesta adalah milik Allah, manusia bukanlah pemilik dari alam, manusia hanyalah di amanahkan untuk menjaga alam dan pada saatnya akan mempertanggungjawabkan perbuatannya terhadap pemilik-Nya. Dalam Al-Quran manusia bersedia menerima amanah yang diberikan oleh Allah, seperti yang terdapat dalam Surah al-Ahzab [33]: 72 :

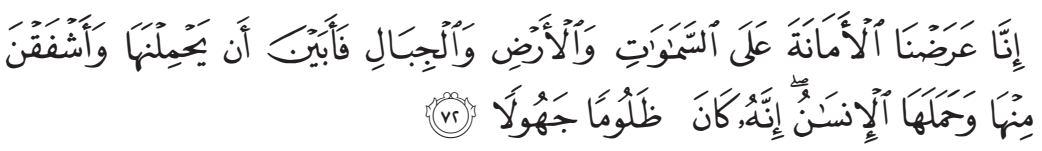

Yang artinya: "sesungguhnya kami telah menawarkan amanat kepada langit, bumi, dan gunung-gunung; tetapi semuanya enggan untuk memikul amanat itu dan mereka khawatir tidak akan melaksanakannya (berat), lalu dipikullah amanat itu oleh manusia, sungguh manusia itu sangat zalim dan bodob” ( QS. Al-Ahzab [33]: 72).

Keunggulan dan kekuatan manusia dalam mengontrol sikapnya terhadap alam dan makhluk lainnya merupakan sebuah amanah yang diterima manusia dari Allah. Sehingga manusia harus mampu menunjukkan tanggungjawab atas pemanfaatan dan pemeliharaan alam dan segala isinya sebagai amanah yang diberikan oleh Allah kepada manusia. Karena sudah menjadi kewajiban bagi manusia sebagai seorang khalifah (pemimpin) dalam mengelola alam. Jikalau manusia melalaikan tugasnya dalam menjaga amanah dan menyalahgunakan, maka manusia telah jatuh dari julukannya sebagai khalifah menjadi seorang yang zalim. Ayat Allah dalam Al-Quran yang memerintahkan manusia untuk amanah dalam menjaga alam dan tidak menjadi zalim atas alam, seperti dalam Al- Baqarah [2]: 205,

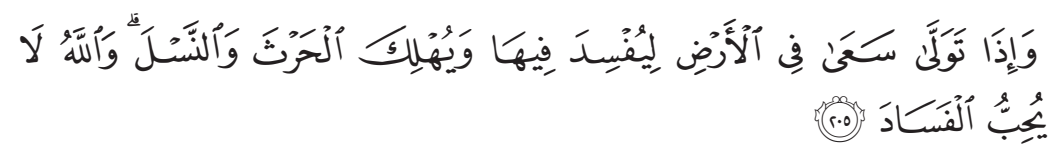

Yang artinya: «.....dan apabila dia berpaling (dari engkau), dia berusaba untuk. berbuat kerusakan di bumi, serta merusak tanam-tanaman dan ternak, sedang Allah tidak menyukai kerusakan" (QS. Al-Baqarah [2] : 205)".

Dalam ayat diatas tampak jelas bahwa manusia diciptakan untuk melindungi dan mengelola alam karena manusia telah 
ditunjuk sebagai khalifah dimuka bumi, sehingga kerusakan yang terjadi terhadap alam merupakan tindakan yang zalim.

\section{c. Akbirah}

Prinsip lainnya yang terkait lingkunagn yaitu konsep islam tentang akhirat atau hal yang berhubungan dengan eskatologi. Umat islam yang beriman akan meyakini bahwa akan adanya kehidupan selanjutnya (akhirat) setelah meninggalnya jasad manusia. Kehidupan di akhirat merupakan konsekuensi kehidupan di dunia. Akhirat, dimana manusia harus mempertanggungjawabkan segala perbuatan yang telah dilakukan selama hidup didunia, baik bersifat vertikal maupun horizontal dalam mengemban tugasnya sebagai khalifah untuk menjaga amanah dalam hal interaksi sesama manusia, interaksi dengan alam, dan interaksi antara manusia dengan sang pencipta. Konsep ini menjadi dasar lahirnya etika terhadap lingkungan yang bersifat holistik dan integral, yaitu dengan adanya konsekuensi dalam setiap perbuatan manusia menjadikan manusia bersikap hati-hati dan mempersiakan apa yang akan di pertanggungjawabkan di akhirat nanti. Dengan konsep ini akan menjadi rambu-rambu dalam pemanfaatan dan pengelolaan manusia terhadap alam. Sehingga manusia tidak seenaknya membuat kerusakan di bumi ini. Manusia tidak dapat bersifat destruktif dan dominasi terhadap alam karena sesungguhnya semua milik Allah dan segalanya akan dipertanggung jawabkan dihadapan Allah.

Ajaran islam tentang manusia sebagai khalifah di muka bumi dan kewajibannya dalam menjaga ekologi dan lingkungan hidup perlu di konstruksi sebagai sebuah sistem keyakinan (aqidah) mengenai nilai akan lingkungan hidup, yang harus dipahami dan diinternalisasikan dalam kehidupan bermasyarakat dan diperjuangkan untuk mencapai misi tersebut. 


\section{Kesimpulan}

Tugas manusia sebagai khalifah adalah untuk menjaga dan bertanggungjawab atas dirinya, sesama manusia dan alam yang menjadi sumber penghidupan. Karena sudah menjadi kewajiban bagi manusia yang merupakan khalifah di bumi memiliki dua bentuk sunatullah yang harus dilakukan, yaitu baik kewajibannya antara manusia dengan tuhannya, antara sesama manusia sendiri, dan antara manusia dengan ekosistemnya. Dampak dari teori Darwin semakin menunjukkan bahwa manusia tidak lagi menjadi makhluk yang bergantung kepada alam, melainkan manusia menjadi faktor penentu atas keberlangsungan alam. Dampak negatif dari hal tersebut semakin menjadikan manusia mencapai level tinggi dalam pengelolaan alam.

Keunggulan dan kekuatan manusia dalam mengontrol sikapnya terhadap alam dan makhluk lainnya merupakan sebuah amanah yang diterima manusia dari Allah. Sehingga manusia harus mampu menunjukkan tanggungjawab atas pemanfaatan dan pemeliharaan alam dan segala isinya sebagai amanah yang diberikan oleh Allah kepada manusia. Karena sudah menjadi kewajiban bagi manusia sebagai seorang khalifah (pemimpin) dalam mengelola alam. Konsep khalifah sebagai yang telah dikemukakan diatas menunjukkan bahwa dalam ajaran islam memiliki relevansi dan perhatian yang sangat besar terhadap konsep ekologis dan lingkungan hidup. Sehingga untuk itu, ajaran islam mengenai konsep ekologis dan lingkungan hidup perlu dikonstruksi sebagai sistem, keyakinan akan nilai-nilai dan cita-cita lingkungan hidup, yang dapat dipahami, ditransformasikan dan diinternalisasikan oleh seluruh umat untuk diperjuangan guna mewujudkan citacita tersebut. 


\section{DAFTAR PUSTAKA}

[1] Arikunto, S. et.al. 2012. Penelitian Tindakan Kela: Pendekatan Kuantitatif, Kualitatif, Dan R\&D. Bandung: Alfabeta.

[2] Fadjar, A. Malik. 2005.Holistika Pemikiran Pendidikan. Jakarta : Raja Grafindo Persada.

[3] Hafsin, Abu. 2007. Islam dan Humanisme: Akulturasi Humanisme Islam di Tengah Krisis Humanisme Universal. Yogyakarta : IAIN Walisongo dengan Pustaka Pelajar.

[4] Hizbut Tahrir Indonesia. 2008. Struktur Negara Khilafah. Jakarta : Dar Al-Ummah.

[5] Khadafi, Ahmad. 2017. Saat Islam Menjadi Agama Mayoritas di Dunia. http://khalifah/Saat-Islam-Menjadi-Agama-Mayoritasdi-Dunia, Tirto.ID.htm, diupload tgl- 6 April 2017.

[6] Madjid, Nurcholish. 2009.Cita-Cita Politik Islam. Jakarta : Paramadina \& Dian Rakyat. Masrokhin. Konsep Ekologi Islam Seyyed Hossein Nasr (Studi Kitab Al-Taharah dalam Kajian Fiqih), Konsep Ekologi Islam, Jurnal Irtifaq, Vol. 1, No 1, 2014.

[7] Moleong, L.J. 2004. Metodologi Penelitian Kualitatif. Bandung: Remaja Rosdakarya.

[8] Mufid, Sofyan Anwar. 2010. Ekologi Manusia. Bandung : Remaja Roesdakarya.

[9] Muhaimin. 2015. Membangun Kecerdasan Ekologis (Model Pendidikan untuk Meningkatkan Kompetensi Ekologis). Bandung: Alfabeta.

[10] Nahdi, Maize Said. Konservasi Ekosistem dan Keanekaragaman Hayati Hutan Tropis Berbasis Masyarakat. Jurnal Kaunia, Vol.4, No.2; hlm 159-172, 2008.

[11] Quddus, Abdul. Ecotheology Islam: Teologi Konstruktif Atasi Krisis Lingkungan, Ulumuba (Jurnal Studi Keislaman), Vol 16, No 2,2012. 
[12] Soemarwoto, Otto. 1987. Ekologi, lingkungan hidup dan pembangunan. Jakarta: Djambatan.

[13] Supriatna, Nana. 2016.Ecopedagogy. Bandung: Remaja Roesdakarya, 2016.

[14] Syakur, M.. Perspektif Pelestarian Lingkungan Hidup dalam Islam, Jurnal Ilmu-Ilmu Pertanian, Vol. 4. No. 1, hlm 44-56, 2008.

[15] Usmani, Ahmad Rofi'. 2016. Jejak-jejak Islam. Yogyakarta : Bunyan.

[16] Wahyu Supraptiningtyas.Tugas Manusia Sebagai Khalifah di Muka Bumi. bttp://blog.unnes.ac.id/ malikhatundayyanab/2015/11/24/tugas.manusia-sebagaikhalifah-di-muka-bumil diupload, pada Minggu, 21 Agustus 2011 21:34 WIB

[17] Zed, Mestika. 2008. Metode Penelitian Kepustakaan . Jakarta: Yayasan Obor Indonesia. 
